\title{
Assessment of maternal serum $\beta$ hCG level in pregnancy induced hypertension and normotensive patients and to correlate between the level of $\beta$ hCG with the severity of pre-eclampsia and eclampsia
}

\author{
Kapil Dev, Anoop Sharma*, Rajeev Sood
}

Department of Obstetrics and Gynecology, Kamla Nehru Hospital, IGMC Shimla, Himachal Pradesh, India

Received: 25 August 2019

Accepted: 30 September 2019

*Correspondence:

Dr. Anoop Sharma,

E-mail: dranoop2012@gmail.com

Copyright: () the author(s), publisher and licensee Medip Academy. This is an open-access article distributed under the terms of the Creative Commons Attribution Non-Commercial License, which permits unrestricted non-commercial use, distribution, and reproduction in any medium, provided the original work is properly cited.

\begin{abstract}
Background: Hypertensive disorders during pregnancy are one of the most common medical complication seen during pregnancy, affecting around 5-10\% of all pregnancies. Spectrum of this disease ranges from mildly elevated blood pressure with minimal clinical significance to severe hypertension with multi organ dysfunction. Pre-eclampsia complicates about $2-8 \%$ of all pregnancies. Pre-eclampsia incidence in India is about 8-10\%. Various studies have depicted that, there is a strict relationship between PIH and elevated serum $\beta$-hCG level.

Methods: This one-year prospective case control study toteled 200 pregnant women attending antenatal care and admitted in eclampsia ward fulfiling the inclusion criteria were studied. Serum $\beta$ hCG levels were estimated by chemiluminescent microparticle immunoassay. Statistical analysis of data was done by student's t-test and p-value.

Results: The mean $\beta$ hCG level in PIH patients was found to $36851.59 \mathrm{mIU} / \mathrm{ml}$ with standard deviation of 22916.58 while the mean $\beta$ hCG in normotensive patient was $15433.26 \mathrm{mIU} / \mathrm{ml}$ with standard deviation of 6861.56 . $(\mathrm{p}<0.001)$. The mean $\beta$ hCG level in gestational hypertensive patients was $25206.19 \mathrm{mIU} / \mathrm{ml}$ with a standard deviation of 8696.9 . The mean $\beta$ hCG level in pre-eclamptic patients was $61697.67 \mathrm{mIU} / \mathrm{ml}$ with standard deviation of 18498.57. The mean $\beta$ hCG level were $84106.38 \mathrm{mIU} / \mathrm{ml}$ with standard deviation of 11295.05 in the eclamptic patient. The above values were statistically significant $(\mathrm{p}<0.001)$.

Conclusions: We concluded that there was a striking relation between the PIH including pre-eclampsia and eclampsia with the elevated serum $\beta$ hCG level. Concluding that early detection of altered serum $\beta$ hCG shell aid in better management of pre-eclampsia and eclampsia cases which would play a pivotal role in improving the maternal and fetal outcome.
\end{abstract}

Keywords: $\beta$ hCG, Pregnancy induced hypertension, Pre-eclampsia and eclampsia

\section{INTRODUCTION}

Hypertensive disorders during pregnancy are one of the most common medical complication seen during pregnancy, affecting around $5-10 \%$ of all pregnancies. ${ }^{1}$ Spectrum of this disease ranges from mildly elevated blood pressure with minimal clinical significance to severe hypertension with multi organ dysfunction. ${ }^{2}$ Pregnancy induced hypertension is considered one of the main public health issue worldwide. $^{3}$ Maternal hypertension is also an important cause of perinatal morbidity and mortility. ${ }^{4}$

Pre-eclampsia complicates about $2-8 \%$ of all pregnancies. ${ }^{5}$ It is responsible for $25 \%$ of all fetal growth retardation and $15 \%$ preterm birth in developed countries. ${ }^{5}$ The incidence of pre-eclampsia in India is 
about $8-10 \%$ and maternal mortality due to preeclampsia is reported to be $8 \% .^{5}$

In PIH, there is mid trimester surge of $\beta$-hCG to overwhelming secretory response of the immunologically modified trophoblast. ${ }^{6}$ The human chorionic gonadotropin (hCG) is a glycoprotein composed of two non-covalently linked subunits, $\alpha$ and $\beta$, and is produced by syncytiotrophoblast cells of the placenta. The free $\beta$ hCG circulating in maternal serum corresponds to only about $0.3-4 \%$ of the total hCG7

Placenta is known primary trigger of Gestation hypertension. It may be considered that early placental vascular damage in preeclemptic pregnancy leading to decreased oxygen supply result in increased beta hCG production by syncytiotrophoblastic cell. ${ }^{8}$

Various studies have depicted that, there is a strict relationship between $\mathrm{PIH}$ and elevated serum $\beta$-hCG level in second and third trimester with adverse pregnancy out comes like in pre-eclampsia. Compared with normal pregnancies, the placenta of patient with unexplained elevated maternal free $\beta$ hCG level tend to be larger. A pregnant woman with elevated $\beta$ hCG level between 16 and 34 weeks of gestation may be suggestive of pre-eclampsia. ${ }^{9}$

This study was conducted to evaluate the relationship between level of serum $\beta$ hCG test in pregnancy induced hypertension and normotensive patients and to correlate between the level of $\beta$ hCG with the severity of Preeclampsia and eclampsia in the Department of OBG, Kamla Nehru Hospital for mother and child, IGMC Shimla

Assessment of maternal serum $\beta$ hCG level in pregnancy induced hypertension and normotensive patients and to correlate between the level of $\beta$ hCG with the severity of Pre-eclampsia and eclampsia.

\section{METHODS}

The present study was a prospective case control study done from July 2016 to July 2017 and included two hundred pregnant women attending antenatal care and admitted in eclampsia ward at Kamla Nehru State
Hospital for Mother and Child, attached to Indira Gandhi Medical College, Shimla. A total of two hundred patients were evaluated in this study after obtaining a written informed consent. Women at POG >22 weeks with Singleton pregnancy were included a hundred Hypertensive women as case group and control group include another hundred normotensive women after matching the parity and gestation age. Women with chronic hypertension, cardiovascular disorder, renal disease, twin pregnancy, molar pregnancy, chromosomally abnormal fetus, diabetes, auto immune disorder, thrombophilia, Family history of diabetes mellitus and cardiovascular disease were excluded from the study. Detailed history was taken according to proforma. A thorough general physical examination, systemic examination, obstetric examination and pelvic examination was done. Various investigations included complete hemogram, platelet count, liver function tests, renal function tests, coagulation profile, fundus examination and 24-hour quantitative estimation of urine protein. Serum $\beta$ hCG levels were estimated by chemiluminescent microparticle immunoassay.

Obstetric management was done according to standard protocol existing in the department. Anticonvulsant and anti-hypertensive drugs were given according to standard protocol. Details of labour whether induced or spontaneous labour, progress of labour and mode of delivery was noted.

\section{Statistical analysis}

Statistical analysis of data was done by student's t-test and p-value.

\section{RESULTS}

In our study 89 patients $(45 \%)$ were between the age group of 25 to 30 years among which 49 patients (55\%) had PIH and rest had normal BP and where around 31 patients $(16 \%)$ were above 30 years, in this age slab 18 patients $(58 \%)$ had high BP while rest were normotensive and the $\mathrm{p}$ value was found to be non-significant.

Majority of the patients both in the hypertensive and normotensive group belonged to rural areas around $62 \%$ $(\mathrm{n}=62)$ and $52 \%(\mathrm{n}=52)$ respectively.

Table 1: The demographic and epidemiological factors of the patient's profile.

\begin{tabular}{|lllll|l|}
\hline Age in year & $\mathbf{P I H}(\mathbf{N}=100)$ & $\%$ & Normotensive $(\mathbf{N}=100)$ & $\%$ & P value \\
\hline$<20$ years & 4 & $67 \%$ & 2 & $33 \%$ & 0.678 \\
\hline 20-25 years & 29 & $39 \%$ & 45 & $61 \%$ & 0.028 \\
\hline $25-30$ years & 49 & $55 \%$ & 40 & $45 \%$ & 0.255 \\
\hline$>30$ years & 18 & $58 \%$ & 13 & $42 \%$ & 0.434 \\
\hline Rural & 63 & $63 \%$ & 52 & $52 \%$ & 0.152 \\
\hline Urban & 37 & $37 \%$ & 48 & $48 \%$ & 0.152 \\
\hline
\end{tabular}


Table 2: Socioeconomic status and BMI.

\begin{tabular}{|c|c|c|c|c|c|}
\hline SES & PIH $(\mathbf{N}=\mathbf{1 0 0})$ & $\%$ & Normotensive ( $\mathbf{N}=\mathbf{1 0 0})$ & $\%$ & P value \\
\hline Upper, upper middle & 11 & $11 \%$ & 30 & $30 \%$ & 0.002 \\
\hline Lower middle & 50 & $50 \%$ & 58 & $58 \%$ & 0.320 \\
\hline \multirow[t]{3}{*}{ Lower } & 39 & $39 \%$ & 12 & $12 \%$ & 0.00002 \\
\hline & PIH & & Normotensive & & $P$ value \\
\hline & Mean & STDEV & Mean & STDEV & \\
\hline BMI $\left(\mathrm{kg} / \mathrm{m}^{2}\right)$ & 23.826 & 1.914 & 22.915 & 1.903 & 0.954 \\
\hline
\end{tabular}

It was observed that PIH was more prevalent in lower middle and lower class of socioeconomic status. Considering the body mass index of the patients, it was concluded that a mean BMI of the patients categorized as pregnancy induced hypertension was $23.826 \mathrm{~kg} / \mathrm{m}^{2}$ with standard deviation of 1.914 .

Table 3: Distribution of patient according to period of gestation.

\begin{tabular}{|llllllll|}
\hline $\begin{array}{l}\text { Gestation age in } \\
\text { weeks }\end{array}$ & $\begin{array}{l}\text { No. of patients } \\
(\mathbf{N}=200)\end{array}$ & $\%$ & $\begin{array}{l}\text { PIH } \\
(\mathbf{N}=100)\end{array}$ & $\%$ & $\begin{array}{l}\text { Normotensive } \\
(\mathbf{N}=100)\end{array}$ & $\%$ & P value \\
\hline$<32$ weeks & 18 & $9 \%$ & 10 & $55.5 \%$ & 8 & $44.5 \%$ & 0.805 \\
\hline $32-34$ weeks & 38 & $19 \%$ & 21 & $55.2 \%$ & 17 & $44.8 \%$ & 0.589 \\
\hline $34-37$ weeks & 114 & $57 \%$ & 59 & $51.7 \%$ & 55 & $48.3 \%$ & 0.668 \\
\hline$>37$ weeks & 30 & $15 \%$ & 10 & $33.3 \%$ & 20 & $66.7 \%$ & 0.073 \\
\hline
\end{tabular}

As shown in the above table 10 patients $(55.5 \%)$ having the gestational age below 32 weeks belongs to PIH (p $=0.805)$. Around 21 patients $(55.2 \%)$ between the gestational age of 32 to 34 weeks had high blood pressure $(\mathrm{p}=0.589)$. A total of 59 patients out of 114 patients $(51.7 \%)$ between the gestational age of 34 to 37 weeks had higher blood pressure and above the gestational age of $>37$ weeks only10 patients $(33.3 \%)$ had high blood pressure $(\mathrm{p}=0.073)$.

Table 4: The systolic and diastolic blood pressure of the patients are depicted below.

\begin{tabular}{|c|c|c|c|c|c|c|c|}
\hline Diastolic BP mmHg & $\begin{array}{l}\text { No. of patients } \\
(N=200)\end{array}$ & $\%$ & $\begin{array}{l}\text { PIH } \\
(\mathrm{N}=100)\end{array}$ & $\%$ & $\begin{array}{l}\text { Normotensive } \\
(\mathrm{N}=100)\end{array}$ & $\%$ & P value \\
\hline$<90$ & 100 & $50 \%$ & 0 & $0 \%$ & 100 & $100 \%$ & $<0.001$ \\
\hline $90-100$ & 80 & $40 \%$ & 80 & $100 \%$ & 0 & $0 \%$ & $<0.001$ \\
\hline $100-110$ & 10 & $5 \%$ & 10 & $100 \%$ & 0 & $0 \%$ & 0.003 \\
\hline$>110$ & 10 & $5 \%$ & 10 & $100 \%$ & 0 & $0 \%$ & 0.003 \\
\hline Systolic BP mmHg & $\begin{array}{l}\text { No. of patients } \\
(\mathrm{N}=200)\end{array}$ & $\%$ & $\begin{array}{l}\text { PIH } \\
(\mathrm{N}=100)\end{array}$ & $\%$ & $\begin{array}{l}\text { Normotensive } \\
(\mathrm{N}=\mathbf{1 0 0})\end{array}$ & $\%$ & P value \\
\hline$<140$ & 100 & $50 \%$ & 0 & $0 \%$ & 100 & $100 \%$ & $<0.001$ \\
\hline $140-150$ & 58 & $29 \%$ & 58 & $100 \%$ & 0 & $0 \%$ & $<0.001$ \\
\hline $150-160$ & 32 & $16 \%$ & 32 & $100 \%$ & 0 & $0 \%$ & $<0.001$ \\
\hline$>160$ & 10 & $5 \%$ & 10 & $100 \%$ & 0 & $0 \%$ & 0.003 \\
\hline
\end{tabular}

As shown in the table above that around 100 patients (50\%) had a systolic blood pressure less than $140 \mathrm{mmHg}$ and belonged to normotensive group. Around 58 women (29\%) had systolic BP ranging between 140 to 150
$\mathrm{mmHg}$ while 32 women (16\%) had systolic BP ranging between 151 to $160 \mathrm{mmHg}$ and only 10 women $(5 \%)$ had systolic above $160 \mathrm{mmHg}$ and belonged to $\mathrm{PIH}$ group. 
It was observed that around 50\% (100 patients) had diastolic blood pressure below $90 \mathrm{mmHg}$. Around 80 women (40\% women) had systolic BP ranging between
90 to $100 \mathrm{mmHg}$ while 10 women (5\% women) had diastolic BP ranging between 100 to $110 \mathrm{mmHg}$ an only 10 women (5\% women) had diastolic above $110 \mathrm{mmHg}$.

Table 5: Distribution of patients according to $\beta$ hCG level in PIH and normotensive patients.

\begin{tabular}{|lllllll|}
\hline Beta hCG mIU/ml & $\begin{array}{l}\text { No. of patient } \\
(\mathrm{N}=200)\end{array}$ & $\begin{array}{l}\mathrm{PIH} \\
(\mathrm{N}=\mathbf{1 0 0})\end{array}$ & $\%$ & $\begin{array}{l}\text { Normotensive } \\
(\mathrm{N}=100)\end{array}$ & $\%$ & P value \\
\hline$<30000$ & 154 & 61 & $39.6 \%$ & 93 & $60.4 \%$ & $<0.001$ \\
\hline $30000-40000$ & 16 & 9 & $56.2 \%$ & 7 & $43.8 \%$ & 0.794 \\
\hline $40000-50000$ & 11 & 11 & $100 \%$ & 0 & $0 \%$ & 0.002 \\
\hline$>50000$ & 19 & 19 & $100 \%$ & 0 & $0 \%$ & $<0.001$ \\
\hline
\end{tabular}

Beta hCG level were associated with the presentation of pregnancy induced hypertension. It was concluded in our study as shown in the table above that a total of 154 patients out of 200 had $\beta$ hCG value of less than 30000 $\mathrm{mIU} / \mathrm{ml}$ in which 61 patients $(39.6 \%)$ were having pregnancy induced hypertension which the rest had normal BP $(\mathrm{p}<0.001)$.
A total of 16 patients out of 200 had $\beta$ hCG value between $30000-40000 \mathrm{mIU} / \mathrm{ml}$ out of which around 9 patients $(56.2 \%)$ had pregnancy induced hypertension while 7 patients $(43.8 \%)$ had normal BP. It was observed that as the value of $\beta$ hCG increased the number of subjects with hypertension also increased but as the value of $\beta$ hCG increased above $40000 \mathrm{mIU} / \mathrm{ml}, 100 \%$ of the subjects had pregnancy induced hypertension.

Table 6: Distribution of patients according to $\beta$ hCG level in gestation hypertension, pre eclemptic and eclemptic $(\mathrm{N}=\mathbf{1 0 0})$.

\begin{tabular}{|lllllll|}
\hline$\beta$ hCG mIU/ml & Eclempsia & $\%$ & Preeclempsia & $\%$ & Gestation hypertension & $\%$ \\
\hline$<30000$ & 0 & $0 \%$ & 0 & $0 \%$ & 61 & $61 \%$ \\
\hline $30000-40000$ & 0 & $0 \%$ & 0 & $0 \%$ & 9 & $9 \%$ \\
\hline $40000-50000$ & 0 & $0 \%$ & 10 & $10 \%$ & 1 & $1 \%$ \\
\hline$>50000$ & 8 & $8 \%$ & 9 & $9 \%$ & 2 & $2 \%$ \\
\hline
\end{tabular}

$\beta$ hCG level were tabulated in the above table and it was seen that $\beta$ hCG level $<30000 \mathrm{mIU} / \mathrm{ml}$ were found in around 61 patient $(61 \%)$ had gestational hypertension. In around 9 patients $(9 \%)$ of gestational hypertension patient had $\beta$ hCG level between 30000-40000 mIU/ml. Only one patient $(1 \%)$ of gestational hypertension patient had $\beta$ hCG level between 40000-50000 $\mathrm{mIU} / \mathrm{ml}$. Only 2 patients $(2 \%)$ of gestational hypertension patient had $\beta$ hCG level >50000 $\mathrm{mIU} / \mathrm{ml}$.

Table 7: Comparison of $\beta$ hCG level in PIH and normotensive.

\begin{tabular}{|llllll|}
\hline & Pregnancy induced hypertension $(\mathrm{N}=100)$ & \multicolumn{1}{l|}{ Normotensive $(\mathrm{N}=100)$} \\
& Mean $\boldsymbol{\beta}$ hCG & Standard deviation & Mean $\boldsymbol{\beta}$ hCG & Standard deviation & p value \\
\hline$\beta \mathrm{hCG} \mathrm{mIU} / \mathrm{ml}$ & 36851.59 & 22916.58 & 15433.26 & 6861.56 & $<0.001$ \\
\hline
\end{tabular}

While in pre-eclempsia only 10 patients $(10 \%)$ had $\beta$ hCG level between $40000-50000 \mathrm{mIU} / \mathrm{ml}$ and 9 patients (9\%) had $\beta$ hCG level $>50000 \mathrm{mIU} / \mathrm{ml}$.

Only 8 patients $(8 \%)$ develop eclempsia and had $\beta$ hCG level $>50000 \mathrm{mIU} / \mathrm{ml}$. It was seen that $\beta$ hCG level was higher in pre-eclempsia and eclempsia patient. So, it was observed that as the value of serum $\beta$ hCG increased the severity of pregnancy induced hypertension also increased from gestation to eclampsia.

The mean $\beta$ hCG level in pregnancy induced hypertensive patients was found to $36851.59 \mathrm{mIU} / \mathrm{ml}$ with standard deviation of 22916.58 while the mean $\beta$ hCG in Normotensive patient was $15433.26 \mathrm{mIU} / \mathrm{ml}$ with standard deviation of 6861.56 ( $\mathrm{p}<0.001)$. 
Table 8: Comparison of $\beta$ hCG level in PIH (Gestational hypertension, pre-eclampsia and eclampsia) (N=100).

\begin{tabular}{|c|c|c|c|c|c|c|c|}
\hline & \multicolumn{2}{|c|}{ Gestational hypertension ( $N=73)$} & \multicolumn{2}{|c|}{ Pre-eclampsia (N=19) } & \multicolumn{3}{|c|}{ Eclampsia (N=8) } \\
\hline & $\begin{array}{l}\text { Mean } \beta \\
\text { hCG }\end{array}$ & Standard deviation & $\begin{array}{l}\text { Mean } \beta \\
\text { hCG }\end{array}$ & $\begin{array}{l}\text { Standard } \\
\text { deviation }\end{array}$ & $\begin{array}{l}\text { Mean } \beta \\
\text { hCG }\end{array}$ & $\begin{array}{l}\text { Standard } \\
\text { deviation }\end{array}$ & $\begin{array}{l}p \\
\text { value }\end{array}$ \\
\hline $\begin{array}{l}\beta \mathrm{hCG} \\
\mathrm{mIU} / \mathrm{ml}\end{array}$ & 25206.19 & 8696.9 & 61697.67 & 18498.57 & 84106.38 & 11295.05 & $<0.001$ \\
\hline
\end{tabular}

As shown in the table below, the mean $\beta$ hCG level in Gestational hypertensive patients was found to be $25206.19 \mathrm{mIU} / \mathrm{ml}$ with a standard deviation of 8696.9. The mean $\beta$ hCG level in pre-eclamptic patients was found to be $61697.67 \mathrm{mIU} / \mathrm{ml}$ with standard deviation of 18498.57. The mean $\beta$ hCG level were $84106.38 \mathrm{mIU} / \mathrm{ml}$ with standard deviation of 11295.05 in the eclamptic patient. The above values were statistically significant ( $p$ $<0.001)$.

\section{DISCUSSION}

Pregnancy induced hypertension including preeclampsia, are important factors of severe morbidity, disability and death among mothers, fetus and neonates. Management of preeclampsia aims to decrease any pregnancy related complications, avoiding unnecessary prematurity and maximize maternal and perinatal/neonatal survival. Preeclampsia and eclampsia are the major causes of maternal and perinatal morbidity and mortality.

In the present study it was found that the mean age of the pregnancy induced hypertensive patients was $27.1 \pm 4.073$ year which was comparatively more than the mean age of normotensive patients and this comparison was found to be statistically insignificant. In the other studies like Yadav S et al, showed that the mean age of PIH patients was 23.24 \pm 3.9 year which was not found to be significant. ${ }^{5}$ Similarly in the study conducted by Remzi et al, concluded that the mean age of the pregnancy induced hypertensive patients was $20.7 \pm 1.1$ year which was comparatively of a younger age group than our study population. ${ }^{10}$

The mean BMI of normotensive patients was $22.91 \pm 1.9$ $\mathrm{kg} / \mathrm{m}^{2}$ and in PIH was $23.082 \pm 1.91 \mathrm{~kg} / \mathrm{m}^{2}$. In the study conducted by Khatun $\mathrm{J}$ et al, mean BMI of normotensive patients was $21.43 \pm 2.09 \mathrm{~kg} / \mathrm{m}^{2}$ and in PIH was $22.02 \pm 1.73 \mathrm{~kg} / \mathrm{m}^{2}$ and the difference was statistically insignificant. $^{11}$

In the study conducted by Begum $\mathrm{Z}$ et al, $50 \%$ of patients in PIH group belonged to lower class, $35.1 \%$ belonged to lower middle and $14.9 \%$ belonged to upper, upper middle class while in the present study $39 \%$ of patients who had pregnancy induced hypertension, belonged to lower class, $50 \%$ belonged to lower middle and $11 \%$ belonged to upper, upper middle class. ${ }^{12}$
It was concluded that the rise in mean systolic and diastolic blood pressure was significant in subjects with PIH.

In the present study mean beta hCG in normotensive group was $15433.26 \pm 6861.56 \mathrm{mIU} / \mathrm{ml}$, while in $\mathrm{PIH}$ group was $36851.59 \pm 22916.58 \mathrm{mIU} / \mathrm{ml}$ and difference were statistically significant with $\mathrm{p}$ value $<0.001$. Therefore, measuring the hCG level would help in early diagnosis of the disease as well as an indicator for the severity of the disease. Similarly, in the study conducted by Yadav $\mathrm{V}$ et al, mean beta hCG in normotensive group was $25365 \pm 11193 \mathrm{mIU} / \mathrm{ml}$ and in PIH group was $71222.22 \pm 1484.7 \mathrm{mIU} / \mathrm{ml}$ and difference were statistically significant with $\mathrm{p}$ value $<0.001 .^{7}$

In another study conducted by Chaudhary KM et al, mean beta hCG in Normotensive group was $8391.06 \pm 1909.64$ $\mathrm{mIU} / \mathrm{ml}$ and in PIH group was 18087.42 \pm 2014.71 $\mathrm{mIU} / \mathrm{ml}$ and difference was statistically significant with $\mathrm{p}$ value $<0.001 .{ }^{13}$ Similarly in the study conducted by Dyal $\mathrm{M}$ et al, mean beta $\mathrm{hCG}$ in normotensive group was $4621.8 \mathrm{mIU} / \mathrm{ml}$ and in PIH group was $16130.2 \mathrm{mIU} / \mathrm{ml}$ and difference was statistically significant with $\mathrm{p}$ value $<0.001 .{ }^{14}$

In the study conducted by Sindu PC, mean beta hCG in normotensive group was $16773 \pm 8150 \mathrm{mIU} / \mathrm{ml}$ and in $\mathrm{PIH}$ group was $40584 \pm 14821 \mathrm{mIU} / \mathrm{ml}$ and difference were statistically significant with $\mathrm{p}$ value $<0.001 .^{15}$

\section{CONCLUSION}

We concluded from the present study that there was a striking relation between the pregnancy induced hypertension including pre-eclampsia and eclampsia with the elevated serum $\beta \mathrm{hCG}$ level indicating that there is abnormal secretory function of placenta established in such cases and which if correlated with the level of the $\beta \mathrm{hCG}$ as an early gestation can help us to recognize the ongoing pathological changes before its progression. The use of these findings would help us to prevent the adverse pregnancy outcomes by more intensive monitoring of the mother and fetus. Concluding that early detection of altered serum $\beta$ hCG shell aid in better management of pre-eclampsia and eclampsia cases which would play a pivotal role in improving the maternal and fetal outcome and further decreasing the morbidity and mortality associated with the same. 
Though in this study we could not conclude the change in the above parameters, in correlation to increased age, increased parity and the different gestational weeks, which may need further evaluation in further studies.

Funding: No funding sources

Conflict of interest: None declared

Ethical approval: The study was approved by the Institutional Ethics Committee

\section{REFERENCES}

1. Mallick MP, Ray S, Medhi R, Bisai S. Eleveted serum beta hCG and dyslipidimia in second trimester as predictor of subsequent pregnancy induced hypertension. Bangladesh Med Res Counc Bull. 2014;40:97-101.

2. Dubey P, Pandey K, Agarwal S, Jain S, Singh N, Gupta S. Effect of Raised midtrimester serum hCG and alfa fetoprotein on pregnancy outcome. Indian $\mathrm{J}$ Clin Pract. 2013;23(10):645-7.

3. Sharma V, Sharma P, Firdous N. Beta hCG in mid trimester as a predictor of pregnancy induced hypertension. Int J Sci Res. 2016;5(9):303-5.

4. Modi DA, Rami BD, Wander GK. Role of serum $\beta$ hcg and lipid profile in early second trimester as predictors of hypertensive disorders of pregnancy. Int J Res Med. 2015;4(4):34-7.

5. Yadav S, Shrivastav N, Paneri S, Pawar P. The study of beta hCG level along with general biochemical profile in pre-eclampsia. IOSR J Dent Med Sci. 2014;13(7):28-1.

6. Singh A, Khambra P, Rani KU, Mandal AK. Assessment of serum $\beta \mathrm{hCG}$, lipid profile and uric acid levels in early second trimester as predictors of pregnancy induced hypertension. Ann Pathol Lab Med. 2016;3(3):157-61.

7. Yadav V, Rathore K, Kaushik GG. A study of beta human chorionic gonadotrophin level in Pre- eclampsia and normotensive pregnant women. Int $\mathbf{J}$ Sci Res. 2015;4(3):1832-3.

8. Chowdhary H, Kurshid R, Praveen S. Utility of second trimester beta hCG levels in prediction of gestational hypertension: a prospective cohart study. Int J Reprod Contracept Obstet Gynaecol. 2017;6(3):1040-4.

9. Dzudor B, Seini MM, Annan BDRT, Srofenyoh E, Kudzi W. The significance of serum level of magnesium and human chorionic gonadotrophin in singleton pregnant women diagnosed with preeclempsia. Int J Adv Res.2014;2(12):569-80.

10. Remzi G, Erdal A, Nursel B, Ozcan B. Elevated $\operatorname{serum} \beta$ hCG level in sever pre-eclempsia. Turk $\mathbf{J}$ Med Sci. 2000;(30):43-5.

11. Khatun J, Amir S. In the pre-eclampsia and normotensive patient- lipid profile study. Med Today. 2017;29(2):1-3.

12. Begum Z, Ara I, Tanira S, Keya KA. The association between $\operatorname{serum} \beta$ hCG and pre-eclempsia. J Dhaka Med Coll. 2014;23(1)89-93.

13. Chaudhary KM, Das M, Gosh S, Bhattacharya D, Gosh TK. Value of serum beta hCG in pathogenesis of Pre-eclempsia. J Clin Gynaecol Obstet. 2012;1(45):71-5.

14. Dyal M, Gupta P, varma M. Role of second trimester maternal serum marker as predictor of pre-eclampsia. J Obstet Gynaecol India. 2011;61(1):38-41.

15. Sindhu PC. Role of second trimester maternal serum marker as predictor of pre-eclampsia. Int $\mathrm{J}$ Med Applied Sci. 2013;2(4):238-43.

Cite this article as: Kapil Dev, Sharma A, Sood R. Assessment of maternal serum $\beta$ hCG level in pregnancy induced hypertension and normotensive patients and to correlate between the level of $\beta$ hCG with the severity of pre-eclampsia and eclampsia. Int J Reprod Contracept Obstet Gynecol 2019;8:4314-9. 